\title{
КРИТЕРІЇ ВИБОРУ ТА ЗМІСТ ФІЗИЧНОЇ ТЕРАПІЇ ОСІБ ІЗ ХРОНІЧНИМ ОБСТРУКТИВНИМ ЗАХВОРЮВАННЯМ ЛЕГЕНЬ
}

\author{
Катерина Тимрук-Скоропад ${ }^{1}$, Юлія Павлова ${ }^{2}$ \\ ${ }^{1}$ Львівський державний університет фізичної культури імені Івана Боберського, м. Львів, Україна, \\ tymruk_k@ukr.net \\ 2 Львівський державний університет фізичної культури імені Івана Боберського, м. Львів, Україна, \\ pavlova.j.o@gmail.com
}

https://doi.org/10.29038/2220-7481-2019-04-96-108

\begin{abstract}
Анотації
Актуальність. Високий рівень захворюваності на хронічне обструктивне захворювання легень (ХОЗЛ), зниження працездатності та висока вартість лікування зумовлюють актуальність пошуку шляхів удосконалення як медичної терапії, так і реабілітації. Доведена ефективність фізичної терапії та програм легеневої реабілітації для пацієнтів із ХОЗЛ зумовлює необхідність імплементувати сучасні напрацювання в цій галузі в клінічну практику в Україні. Мета статті - обгрунтувати обсяг і зміст фізичної терапії пацієнтів із хронічним обструктивним захворюванням легень на різних рівнях надання медичної допомоги. Методи дослідження - аналіз та узагальнення даних спеціальної науково-методичної літератури 3 питань фізичної терапії при хронічному обструктивному захворюванні легень, опрацювання інтернет-джерел, зокрема бази Національної медичної бібліотеки Національного інституту здоров'я Сполучених Штатів (US National Library of Medicine National Institutes of Health) та бази доказової літератури з фізичної терапії Pedro. Результати. На основі аналізу 13 клінічних настанов стосовно менеджменту й реабілітації осіб із ХОЗЛ, ураховуючи законодавчі акти Міністерства охорони здоров'я України, запропоновано алгоритм вибору фізичної терапії для пацієнтів із ХОЗЛ та схарактеризовано її особливості з урахуванням перебігу захворювання. Сформовано рекомендації щодо обсягу фізичної терапії залежно від перебігу захворювання й рівнів надання медичної допомоги. Висновки. Фізична терапія $\epsilon$ необхідним компонентом реабілітації в період загострення хронічного обструктивного захворювання легень та обов'язкова частина програм легеневої реабілітації при стабільному перебігу ХОЗЛ. Критеріями вибору обсягу фізичної терапії визначено стан хворого, рівень задишки, показник ОФВ ${ }_{1}$, рівень фізичної активності та працездатності.
\end{abstract}

Ключові слова: легенева реабілітація, ХОЗЛ, фізична активність, загострення.

Катерина Тимрук-Скоропад, Юлия Павлова. Критерии выбора и содержание физической терапии пациентов с хронической обструктивной болезнью легких. Актуальность. Высокий уровень заболеваемости хроническим обструктивным заболеванием легких (ХОБЛ), снижение работоспособности и высокая стоимость лечения обусловливают актуальность поиска путей совершенствования как медицинской терапии, так и реабилитации. Доказана эффективность физической терапии и программ легочной реабилитации пациентов с ХОБЛ вызывает необходимость имплементировать современные наработки в этой области в клиническую практику в Украине. Цель статьи - обосновать объем и содержание физической терапии пациентов с хроническим обструктивным заболеванием легких на разных уровнях оказания медицинской помощи. Meтоды исследования - анализ и обобщение данных специальной научно-методической литературы по вопросам физической терапии при хроническом обструктивном заболевании легких, обработки интернетисточников, в том числе базы Национальной медицинской библиотеки Национального института здоровья Соединенных Штатов (US National Library of Medicine National Institutes of Health) и базы доказательной литературы по физической терапии Pedro. Pезультаты. На основе анализа 13 клинических руководств посвященных менеджменту и реабилитации лиц с ХОБЛ, учитывая законодательные акты Министерства здравоохранения Украины, предлагается алгоритм выбора физической терапии для пациентов с ХОБЛ характеризируются ее особенности с учетом течения заболевания. Сформированы рекомендации по объему физической терапии в зависимости от течения заболевания и уровней оказания медицинской помощи. Bbыбоды. Физическая терапия является необходимым компонентом реабилитации в период обострения хронического обструктивного заболевания легких и обязательная часть программы легочной реабилитации при стабильном течении ХОБЛ. Критериями выбора объема физической терапии определяется состояние больного, уровень одышки, показатель ОФВ1, уровень физической активности и работоспособности.

Ключевые слова: легочная реабилитация, ХОБЛ, физическая активность, обострение.

Kateryna Tymruk-Skoropad, Iuliia Pavlova. Selection Criteria and Content of Physical Therapy for Persons with Chronic Obstructive Pulmonary Disease. Topicality. The high incidence of chronic obstructive 
pulmonary disease (COPD), decreased working ability and the high cost of treatment make important to find ways to improve both medical therapy and rehabilitation. The effectiveness of physical therapy and pulmonary rehabilitation programs for patients with COPD has been proved. The implementation of modern developments in this area to clinical practice is necessary in Ukraine. The Purpose of the Research is to substantiate the scope and the content of physical therapy for patients with chronic obstructive pulmonary disease at the different levels of medical care. The Research Methods. Analysis and generalization of data from special scientific and methodological literature on physical therapy of COPD have been conducted, also online sources, including the database of the National Medical Library of the National Institute of Health of the United States and the evidence base of physical therapy Pedro have been processed. The Results of the Research. An algorithm for choosing physical therapy for patients with COPD was proposed. It based on analysis of 13 clinical guidelines of the management and rehabilitation of COPD taking into account the laws of the Ministry of Health of Ukraine and the course of the disease. Recommendations on the scope of physical therapy, depending on the course of the disease and levels of medical care have been formulated. Conclusions. Physical therapy is a necessary component of rehabilitation during COPD exacerbation and is an essential part of a pulmonary

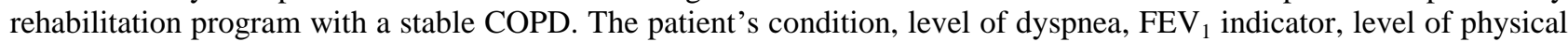
activity and working capacity were determined like criteria of the scope of physical therapy.

Key words: pulmonary rehabilitation, COPD, physical activity, exacerbation.

Вступ. Хронічне обструктивне захворювання легень (ХОЗЛ) залишається однією $з$ основних причин смерті в різних країнах світу [27]. Висока вартість лікування, утрата працездатності пацієнта через прогресування захворювання зумовлюють постійний запит суспільства на вдосконаленні як медичної терапії, так і реабілітації. В останніх рекомендаціях Глобальної ініціативи з хронічного обструктивного захворювання легень (Global Initiative for Chronic Obstructive Lung Disease) [14] зазначено, що ХОЗЛ можна попередити, лікувати й сповільнити його розвиток. Терапія та менеджмент пацієнтів із ХОЗЛ ускладняються через загострення, розвиток системних змін в організмі та супутніх патологій. Саме важкі загострення є основними чинниками, які спричиняють прогресування хвороби [21], а супутні захворювання - суттєвого погіршення якості життя пацієнта вже на початковій стадії ХОЗЛ [4]. Ці чинники впливають на зростання ризику смерті особи з ХОЗЛ і суттєво збільшують витрати охорони здоров’я на лікування таких пацієнтів [20].

Фізичну терапію (ФТ) як самостійний елемент чи як компонент легеневої реабілітації (ЛР) застосовують для пацієнтів із ХОЗЛ незалежно від ступеня та періоду захворювання. Для ефективної терапії осіб із ХОЗЛ потрібно напрацювати чіткий механізм уключення цих пацієнтів у легеневу реабілітацію, урахувати сучасні практики надання реабілітаційної допомоги під час вибору змісту фізичної терапії, наповненості індивідуальної програми залежно від рівня медичної допомоги.

Мета статті - обгрунтувати обсяг та зміст фізичної терапії пацієнтів із хронічним обструктивним захворюванням легень на різних рівнях надання медичної допомоги.

Матеріал і методи дослідження. Аналіз й узагальнення даних спеціальної науково-методичної літератури 3 питань фізичної терапії при хронічному обструктивному захворюванні легень; метод аналізу медичної документації; опрацювання інтернет-джерел, зокрема бази Національної медичної бібліотеки Національного інституту здоров'я Сполучених штатів (US National Library of Medicine National Institutes of Health) і бази доказової літератури з фізичної терапії Pedro.

Пошук обмежувався публікаціями за п’ять останніх років, які стосувалися клінічних настанов щодо лікування й менеджменту, легеневої реабілітації та фізичної терапії пацієнтів із ХОЗЛ.

Дослідження, уведені в аналіз, відповідали таким критеріям: 1) вивчають хронічне обструктивне захворювання легень; 2) огляд, рекомендації чи практичні настанови із загальних принципів лікування, ведення, реабілітації чи фізичної терапії при ХОЗЛ.

Критерії виключення з аналізу: 1) систематичні огляди; 2) реферати конференцій без повнотекстового огляду; 3) неповні текстові статті; 4) книги; 5) зареєстровані протоколи клінічних досліджень; 6) національні адаптації рекомендації BOO3 GOLD.

На основі аналізу відібраних 13 клінічних настанов із менеджменту та реабілітації осіб із хронічним обструктивним захворюванням легень синтезовано основні рекомендації щодо критеріїв вибору програми фізичної терапії.

Результати дослідження. Фізичну терапію застосовують у пацієнтів зі стабільним перебігом ХОЗЛ та при загостренні основного захворювання [3].

У пацієнтів зі стабільним перебігом ХОЗЛ застосування фізичної терапії рекомендовано в межах легеневої реабілітації (програма мультидисциплінарної реабілітації) або програми фізичної активності під керівництвом фізичного терапевта як частину первинної медичної допомоги. 
Окрім легеневої реабілітації та фізичної активності, пацієнтів із легкими та середніми порушеннями (I i II ступінь) і незначним зниженням фізичної витривалості (задишка на оцінку $\leq 2$ бали за шкалою Медичної дослідницької ради (MRC) можна залучати до регулярної адаптованої спортивної активності (спеціально підібраних занять фізичною культурою та спортом).

Критеріями вибору обсягу послуг із фізичної терапії для пацієнтів із ХОЗЛ є стан хворого, рівень задишки, показник ОФВ 1 , рівень фізичної активності та працездатності (рис. 1).

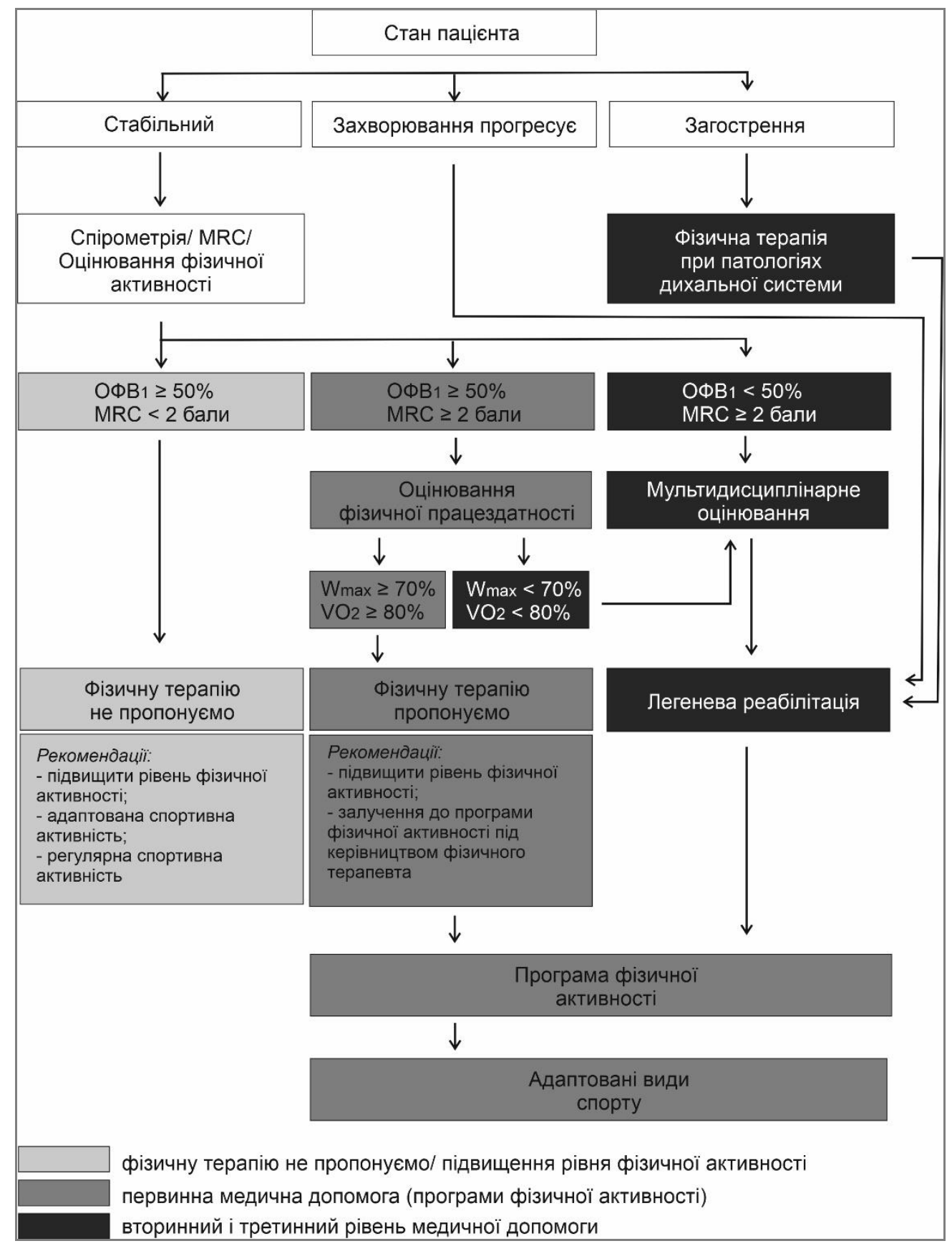

Рис. 1. Алгоритм вибору обсягу фізичної терапї̈ для пачієнтів із ХОЗЛ

Примітки. MRC - шкала Медичної дослідницької ради (для визначення рівня задишки), ОФВ форсованого видиху за першу секунду видиху, $W_{\text {max }}$-максимальне навантаження, $\mathrm{VO}_{2}$ - споживання кисню.

Пацієнти із ХОЗЛ, які мають стабільний стан, показники ОФВ $1 \geq 50 \%$ від належного значення, рівень задишки за шкалою MRC < 2 балів, не потребують обов’язкової фізичної терапії [15]. Основними рекомендаціями є підвищення фізичної активності та заняття адаптованими видами спорту. 
Пацієнтам зі стабільним перебігом можемо рекомендувати програми фізичної активності й легеневої реабілітації, якщо показники $\mathrm{OФB}_{1} \geq 50 \%$ та оцінка задишки за шкалою MRC $\geq 2$ бали. Визначення рівня фізичної витривалості дає змогу більш точно дібрати варіант фізичної терапії (програму фізичної активності або легеневу реабілітацію) [1]. На сьогодні немає однозначних рекомендацій щодо того, яким саме категоріям пацієнтів із ХОЗЛ обов'язково потрібно визначати рівень фізичної витривалості та працездатності. Найчастіше це рекомендують для пацієнтів похилого віку, осіб, які мають проблеми із серцево-судинною системою, страждають на ХОЗЛ, проте в деяких клінічних настановах [29] зазначено, що тести на фізичну витривалість і працездатність потрібно проводити для всіх пацієнтів із ХОЗЛ.

Для участі в програмі легеневої реабілітації потрібно скеровувати пацієнтів, які мають низькі показники функції дихальної системи (ОФВ1 < 50 \% від належного), значну задишку (показник за шкалою $\mathrm{MRC} \geq 2$ бали), низький рівень фізичної працездатності [8], осіб із прогресуванням ХОЗЛ, або після загострення цієї хвороби. Після завершення програми легеневої реабілітації такі пацієнти можуть продовжувати фізичну терапію за програмами фізичної активності.

Для пацієнтів із загостреннями, окрім медикаментозного лікування, потрібно запланувати фізичну терапію. Після стабілізації стану пацієнту доцільно запропонувати якнайшвидше (упродовж місяця) розпочати програму легеневої реабілітації.

Варіанти застосування та послідовні етапи фізичної терапії осіб із ХОЗЛ залежно від перебігу захворювання, функціонального стану дихальної системи, рівня фізичної працездатності запропоновано в табл. 1.

Таблиия 1

\section{Фізична терапія з урахуванням перебігу ХОЗЛ}

\begin{tabular}{|c|c|c|c|c|c|}
\hline $\begin{array}{c}\text { Перебіг } \\
\text { захворювання }\end{array}$ & $\begin{array}{c}\text { Особливість } \\
\text { програми } \\
\text { фізичної } \\
\text { терапії }\end{array}$ & $\begin{array}{c}\text { Вид реабілітації } \\
\text { відносно місця } \\
\text { проведення }\end{array}$ & $\begin{array}{c}\text { Рекомендована } \\
\text { тривалість } \\
\text { програми/ } \\
\text { кількість } \\
\text { сеансів } \\
\end{array}$ & $\begin{array}{c}\text { Рівень } \\
\text { надання } \\
\text { медичної } \\
\text { допомоги }\end{array}$ & Наступні кроки \\
\hline \multirow{6}{*}{$\begin{array}{c}\text { Стабільний } \\
\text { стан }\end{array}$} & \multirow{6}{*}{$\begin{array}{l}\text { Фізична } \\
\text { терапія під } \\
\text { час програми } \\
\text { легеневої } \\
\text { реабілітації }\end{array}$} & \multirow{2}{*}{$\begin{array}{l}\text { Домашня програ- } \\
\text { ма (за неможливо- } \\
\text { сті особи відвідува- } \\
\text { ти амбулаторію) }\end{array}$} & \multirow{2}{*}{$\begin{array}{l}\text { 6-8 тижнів / } \\
\text { до } 2 \text { сеансів на } \\
\text { тиждень }\end{array}$} & Первинний & \multirow[t]{2}{*}{-} \\
\hline & & & & Вторинний & \\
\hline & & \multirow{2}{*}{ Амбулаторна } & \multirow{2}{*}{$\begin{array}{l}\text { 6-8 тижнів/ } \\
\text { 2-3 сеанси на } \\
\text { тиждень }\end{array}$} & Первинний & \multirow{2}{*}{$\begin{array}{l}\text { Домашня-програма } \\
\text { (за потреби) }\end{array}$} \\
\hline & & & & Вторинний & \\
\hline & & \multirow{2}{*}{$\begin{array}{l}\text { Стаціонарна } \\
\text { (важкий стан па- } \\
\text { цієнта, прогресу- } \\
\text { вання захворю- } \\
\text { вання) }\end{array}$} & \multirow{2}{*}{$\begin{array}{l}\text { Період перебуван- } \\
\text { ня в стаціонарі } \\
\text { спеціалізованого } \\
\text { відділення/1 сеанс } \\
\text { на день }\end{array}$} & Вторинний & \multirow[b]{2}{*}{$\begin{array}{l}\text { Амбулаторна, до- } \\
\text { машня програма } \\
\text { легеневої реабі- } \\
\text { літації (за потреби) }\end{array}$} \\
\hline & & & & Третинний & \\
\hline \multirow{4}{*}{ Загострення } & \multirow{4}{*}{$\begin{array}{l}\text { Фізична } \\
\text { терапія при } \\
\text { порушеннях } \\
\text { діяльності } \\
\text { дихальної } \\
\text { системи }\end{array}$} & \multirow{2}{*}{$\begin{array}{l}\text { Стаціонарна } \\
\text { (пацієнти } 3 \text { важ- } \\
\text { ким загострен- } \\
\text { ням) }\end{array}$} & \multirow{2}{*}{$\begin{array}{l}\text { Упродовж період } \\
\text { перебування в } \\
\text { стаціонарі/ } \\
\text { від } 1 \text { сеансу на } \\
\text { день } \\
\end{array}$} & Вторинний & \multirow{4}{*}{$\begin{array}{l}\text { Фізична терапія } \\
\text { (програма легеневої } \\
\text { реабілітаціі) }\end{array}$} \\
\hline & & & & Третинний & \\
\hline & & \multirow{2}{*}{$\begin{array}{l}\text { Амбулаторна } \\
\text { (загострення } \\
\text { легкої та помірної } \\
\text { тяжкості) }\end{array}$} & \multirow{2}{*}{$\begin{array}{l}\text { До стабілізації } \\
\text { стану пацієнта / } \\
1 \text { сеанс на день }\end{array}$} & Первинний & \\
\hline & & & & Вторинний & \\
\hline
\end{tabular}

Послідовність застосування програми легеневої реабілітації для пацієнтів із ХОЗЛ подано на рис. 2.

Легенева реабілітація (рис. 3) - це науково обгрунтоване терапевтичне втручання [10], рекомендоване пацієнтам із ХОЗЛ (зокрема за наявності інших супутніх хвороб), які, незважаючи на наявність оптимальної фармакологічної терапії, мають чітко виражені симптоми захворювання [7].

Залежно від наявності спеціалістів, матеріально-технічного оснащення, потреб та запитів пацієнтів, склад команди фахівців, які здійснюють легеневу реабілітацію, тривалість і види реабілітації можуть суттєво відрізнятися [3]. 


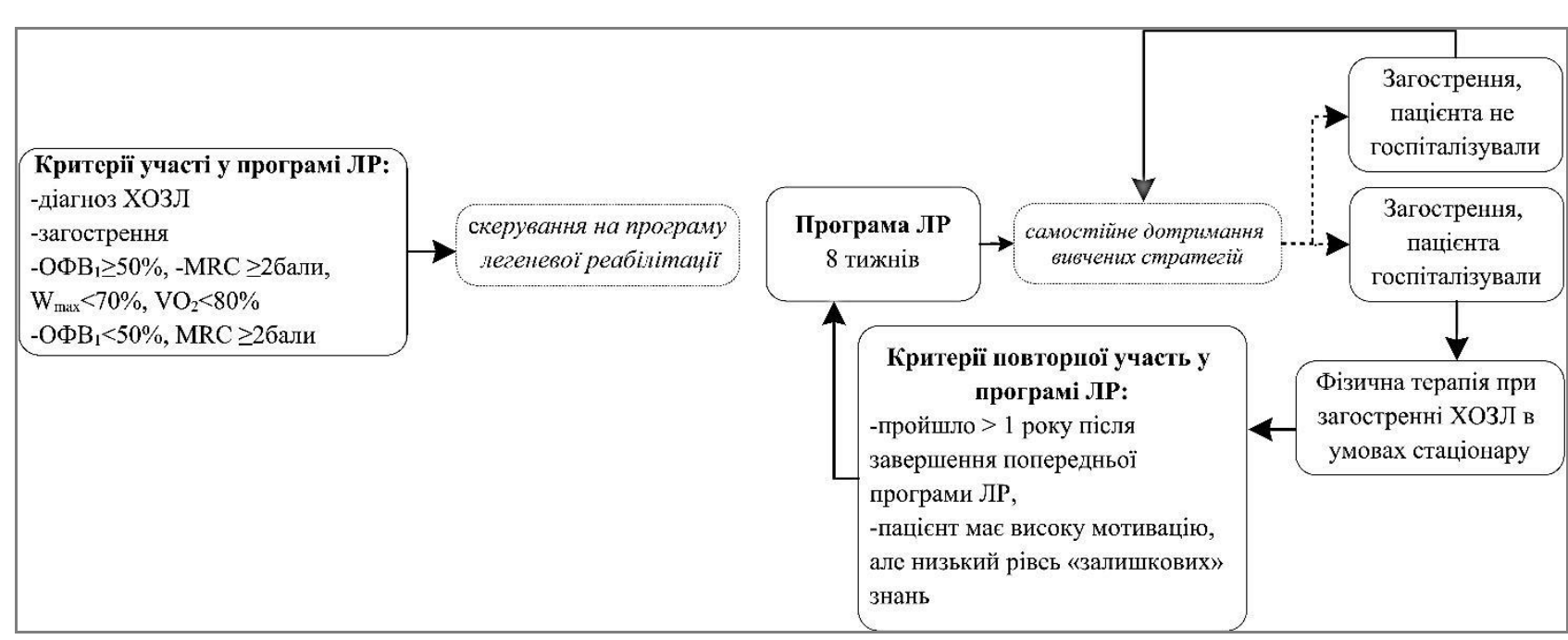

Рис. 2. Алгоритм включення осіб із ХОЗЛ у програму легеневої реабілітащії

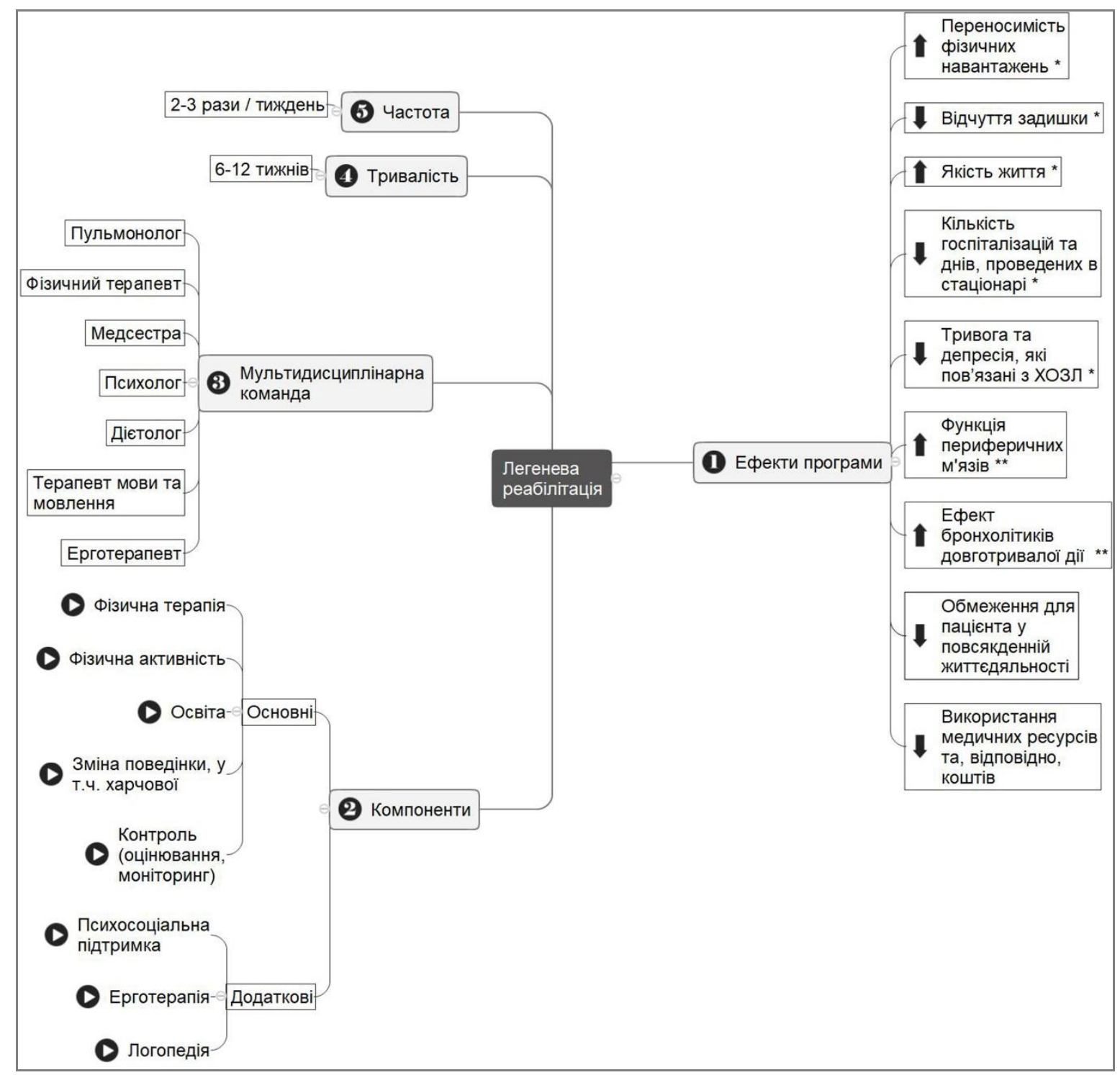

Рис. 3. Програми легеневої реабілітайї: їх вплив, ефекти та компоненти

Примітки. * - рівень доказів $A$; ** - рівень доказів $B$. 
Якщо стан пацієнта стабільний, програму легеневої реабілітації в домашніх умовах можемо розглядати як альтернативу амбулаторній програмі. Їй потрібно надати перевагу, якщо пацієнт не може виходити з дому через стан здоров'я або не може відвідувати амбулаторію (кабінет, відділення, клініку тощо), оскільки вона розміщена надто далеко, або не може до неї добиратися.

Наповнення програми легеневої реабілітації залежать від теоретико-методичного та матеріальнотехнічного забезпечення, наявності відповідно підготованих фахівців, фінансування програми. Розрізняють основні та додаткові компоненти програм легеневої реабілітації:

- фізична терапія (у т. ч. фізична активність, фізичне тренування);

- освіта;

- зміна поведінки (у т. ч. харчової й припинення куріння);

- контроль (у т. ч. оцінювання).

Вагоме значення в програмах має надання психосоціальної підтримки, модифікація поведінки (зокрема харчової), ерготерапія та логопедична допомога.

Амбулаторні програми легеневої реабілітації найбільш поширені, їх потрібно розглядати як пріоритетний варіант надання реабілітаційної допомоги, вони мають доведену ефективність і пролонговані впливи. На програми легеневої реабілітації в умовах амбулаторії скеровують пацієнтів (1), у яких ХОЗЛ виявили вперше та які відповідають критеріям для призначення легеневої реабілітації; (2) котрі вже мають діагноз ХОЗЛ та відповідають критеріям для призначення легеневої реабілітації; (3) після загострення ХОЗЛ; (4) для повторного проходження програми, якщо позитивні ефекти, досягнуті попередньою програмою, знижуються.

Якщо стан пацієнта важкий, ХОЗЛ (основне захворювання) прогресує або є загострення, яке потребує госпіталізації, тоді реабілітація обмежується переважно фізичною терапією й повинна здійснюватися в стаціонарі. Заходи фізичної терапії, що почались у стаціонарні, можуть тривати в амбулаторних умовах і після стабілізації стану пацієнта продовжуватись у вигляді легеневої реабілітації.

Під час загострення ХОЗЛ запальні процеси в дихальних шляхах посилюються, функції дихання погіршуються, збільшується прояв задишки, зростає об'єм мокротиння та змінюється його якість, 3'являються сухі хрипи. Це вимагає призначення додаткової терапії [18].

Під час загострення, коли пацієнт перебуває в стаціонарі, фізична терапія спрямована на зменшення та усунення основних симптомів, причин їх погіршення з боку дихальної системи (рис. 4). Діяльність фізичного терапевта спрямована на очищення дихальних шляхів пацієнта, поліпшення легеневої вентиляції, зменшення проявів задишки, зменшення гіперінфляції легень та іï проявів, поліпшення функціонального стану основних і додаткових дихальних м'язів, нормалізацію патерну дихання.

Вибір конкретних утручань, які увійдуть у програму фізичної терапії, проводять з урахуванням результатів реабілітаційного обстеження. Ці втручання можна продовжувати використовувати в програмах фізичної терапії, а також після виписки пацієнта зі стаціонару в амбулаторній або домашній програмі легеневої реабілітації.

На завершальному етапі перебування пацієнта в стаціонарі можуть частково застосовуватися фізичні вправи та зміна рівня фізичної активності (рис. 5). Надалі обсяг фізичного тренування та фізичної активності збільшується.

Можливість витримувати фізичне навантаження в пацієнтів із ХОЗЛ порушена й часто обмежена задишкою. Фізичне тренування - ефективний і доступний засіб поліпшення м'язової функції при ХОЗЛ (рис. 6).

Для осіб із ХОЗЛ характерне зниження рівня фізичної активності, переважання сидячого способу життя. Тому важливим залишається питання стимулювання щоденної активності, заохочення до підвищення рівня фізичної активності відповідно до рекомендацій Всесвітньої організації охорони здоров'я для здорових людей.

Дискусія. Згідно з уніфікованим клінічним протоколом первинної, вторинної (спеціалізованої), третинної (високоспеціалізованої) медичної допомоги та медичної реабілітації (наказ МОЗ України №555 від 27 червня 2013 р.) для хронічного обструктивного захворювання легень передбачено низку заходів реабілітаційної допомоги відповідно до рівня надання медичної допомоги.

Зокрема, на первинному рівні заходи/втручання, що стосуються фізичної терапії, містять:

- консультацію фізичного терапевта;

- розробку освітніх програми;

- респіраторну фізіотерапію (діафрагмальне дихання, видихання через підтиснуті губи, технологію форсованого видиху, дренаж із мануальною перкусією); 
- навчання пацієнтів, які мають надмірне виділення харкотиння, правильного використання дихальних масок із позитивним тиском та дихальних тренажерів.

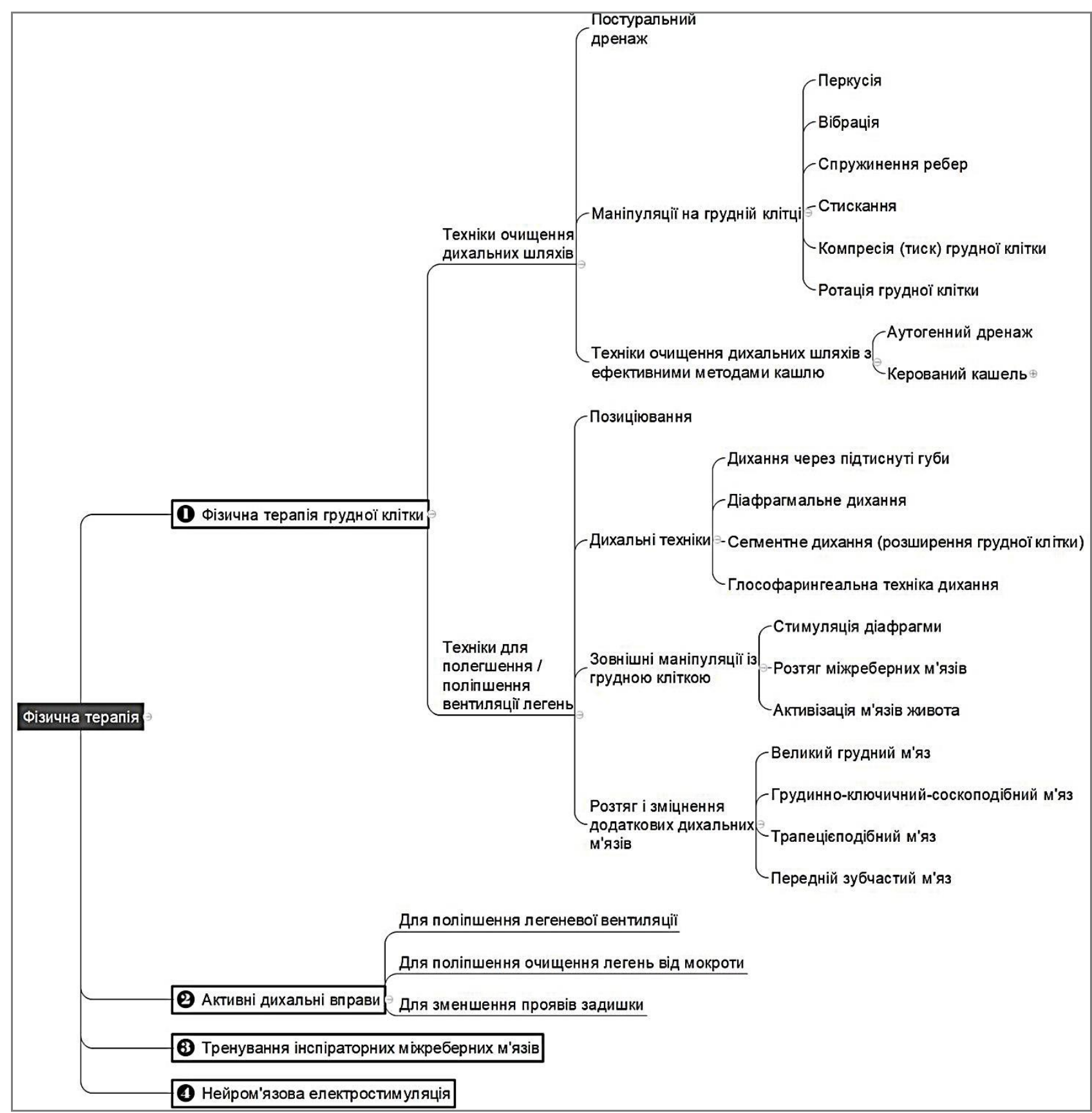

Рис. 4. Засоби фізичної терапії, які використовують у програмах легеневої реабілітації для паџієнтів із загостренням ХОЗЛ

На вторинному й третинному рівнях передбачено консультації фізичного терапевта та підбір ним дихальної гімнастики.

Зважаючи на вищенаведене, можливість отримувати медичну та реабілітаційну допомогу на всіх рівнях без обмежень залежно від ступеня важкості захворювання доцільна для того, щоб ліпше організувати надання реабілітаційної допомоги, ураховувати особливості періодів стабільного перебігу ХОЗЛ і загострення.

Однак за допомогою аналізу та порівняння сучасних зарубіжних практик надання реабілітаційної допомоги особам із ХОЗЛ та заходів, рекомендованих вітчизняним протоколом, виявлено, що рекомендації щодо фізичної терапії при загостреннях ХОЗЛ і надання реабілітаційної допомоги в умовах стаціонару й амбулаторії в Україні напрацьовані недостатньо. У зв'язку з тим, що домашні програми в 
Україні відсутні, частина хворих не може отримати передбачені та необхідні послуги. Програма легеневої реабілітації має фрагментарний характер, іiї чіткий опис наявний лише для періоду санаторнокурортного лікування.

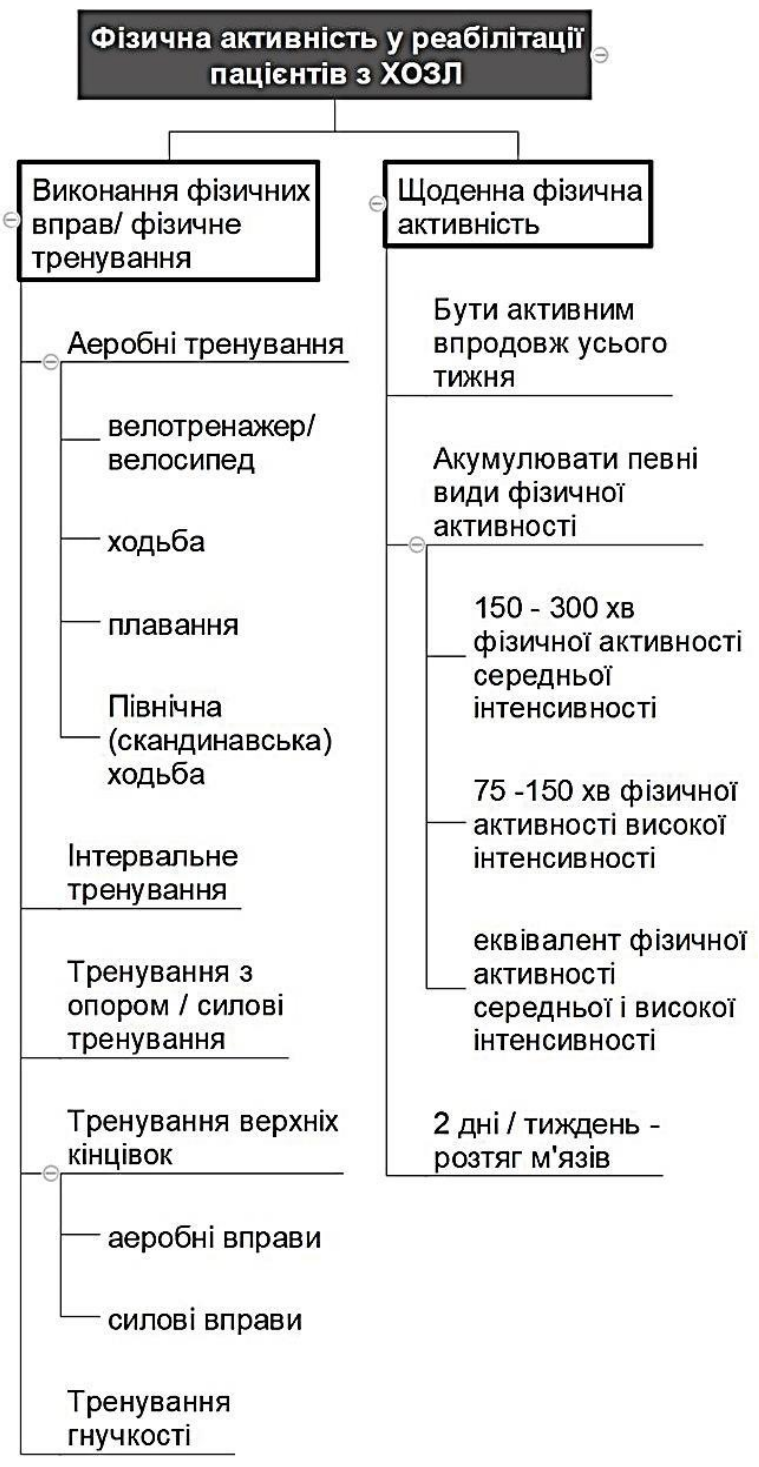

Рис. 5. Зміст фізичного тренування та фізичної активності в реабілітайї паџієнтів із ХОЗЛ

Легенева реабілітація повинна стати ключовою стратегією менеджменту пацієнтів із ХОЗЛ, вийти за рамки академічних і теоретичних досліджень та стати цілісним, комплексним, повноцінно сформованим міждисциплінарним утручанням [13]. Мета легеневої реабілітації - зменшення проявів захворювання, подолання характерних фізичних чи функціональних обмежень. Причини цих обмежень дуже piзні. Це, зокрема, утрата м'язової маси, сили й витривалості [2], зниження функції дихання через слабкість дихальних м'язів, неефективний газообмін, зростання частоти дихання, а також порушення функції серцево-судинної системи. Окрім фізичних обмежень, пацієнти з ХОЗЛ мають високий рівень депресії та тривоги, що призводить до соціальної ізоляції й зростання потреби в спеціальній допомозі. Щоб розв'язати такі дуже різні проблеми, склад типової міждисциплінарної групи з легеневої реабілітації може відрізнятися й ураховувати потреби пацієнта на різних етапах захворювання. Серед фахівців групи чільне місце займають пульмонолог, фізичний терапевт, дієтолог, психолог, рідше в команді $є$ ерготерапевт та логопед [16]. Кожен із них, залежно від стану пацієнта, його фізичних можливостей, періоду захворювання, забезпечує втручання, які дають змогу поліпшити функціональний стан дихальної системи, фізичну працездатність, зменшити кількість загострень і госпіталізацій, покращити якість життя хворого. 


\section{Тип фізичного тренування}

\section{Тренування на витривалість (аеробні)}

Mema: поліпшити аеробні можливості, що дасть змогу виконувати повсякденні завдання із меншими енергетичними затратами.

Критерії вибору: усі особи з ХОЗЛ, які проходять програму легеневої реабілітації.

Варіанти проведення: бігова доріжка, велоергометер, плавання, скандинавська ходьба

абор

\section{Інтервальні тренування}

Mema: поліпшити аеробні можливості та здатність витримувати фізичне навантаження.

Критерії вибору: альтернатива тренуванню на витривалість; особи, які не можуть безперервно підтримувати фізичне навантаження необхідної інтенсивності.

Варіанти проведення: бігова доріжка, велоергометер

\section{Силові тренування}

Mema: збільшити силу м'язів нижніх і верхніх кінцівок, тулуба. Критерії вибору: усі особи з ХОЗЛ, які проходять програму легеневої реабілітації, зокрема ті, які мають знижену силу периферичних м'язів.

Варіанти проведення: обтяження власною вагою, зовнішнім обтяженням та еластичними стрічками

\section{Тренування верхніх кінцівок}

Mema: збільшити силу і витривалість м'язів верхніх кінцівок. Критерії вибору: усі особи з ХОЗЛ, які проходять програму легеневої реабілітації, зокрема ті, які мають знижену силу периферичних м'язів.

Варіанти проведення: обтяження власною вагою, зовнішнім обтяженням та еластичними стрічками

\section{Тренування гнучкості}

Mema: збільшити силу й витривалість м'язів нижніх кінцівок Критерії вибору: усі особи з ХОЗЛ, які проходять програму легеневої реабілітації, зокрема ті, які мають знижену силу периферичних м'язів.

Варіанти проведення: обтяження власною вагою, зовнішнім обтяженням та еластичними стрічками
Методичні рекомендації

Yастота: 3 рази/ тиждень Tривалість: не менше 20 хв. Контроль: шкала Борга

Yастота: 3 рази/ тиждень Дозування: 1) 30-60 с навантаження інтенсивністю 90 100 \% від максимального, співвідношення навантаження/відновлення - 1:2, 2) 2-3 хв із навантаження 3 інтенсивністю $70 \%$ від максимальної, співвідношення 2:1. Контроль: шкала Борга

Yacmoma: 2 рази/ тиждень Дозування: 60-80 \% від максимальної ваги, 2-3 підходи по 8-12 повторів на кожну обрану групу м'язів

Yастота: 2 рази/ тиждень Дозування: 60-80 \% від максимальної ваги, 2-3 підходи по 8-12 повторів на кожну обрану групу м'язів

Yacmoma: 2 рази/ тиждень Дозування: 60-80 \% від максимальної ваги, 2-3 підходи по 8-12 повторів на кожну обрану групу м'язів

Рис. 6. Особливості та зміст фізичного тренування в програмі легеневої реабілітаиії осіб із ХОЗЛ: * - рекомендовано використовувати шкалу Борга для контролю за станом паиієнта

У період загострення ХОЗЛ доцільно застосовувати фізичну терапію, що відповідає стану, ураховує клінічний перебіг захворювання та містить ефективні при патологіях дихальної системи втручання. Усім пацієнтам, які мали загострення ХОЗЛ, у подальшому рекомендують пройти програму легеневої реабілітації. Її можна розпочинати якнайшвидше після загострення [31] або впродовж одного місяця після виписки з лікарні [4].

На сьогодні амбулаторні реабілітаційні програми є ефективним засобом терапії пацієнтів з ХОЗЛ, вони суттєво збільшують функціональну працездатність хворого [24]. Натомість довготривалі ефекти 
від терапії залежать від різних чинників. Позитивні наслідки реабілітаційного втручання зберігаються до дев'яти місяців після терапії, а потім поступово знижуються $[5,25]$. Усі позитивні ефекти легеневої реабілітації, серед яких - і підвищення рівня фізичної працездатності, ніяким чином не пов'язані зі збільшенням рівня щоденної активності $[9,17]$. Натомість зниження рівня фізичної активності призводить до збільшення ризиків загострення стану пацієнтів із ХОЗЛ [11]. Хорошою альтернативою амбулаторній реабілітації можуть бути різноманітні програми домашніх занять, ефективність яких підтверджена рандомізованими клінічними дослідженнями [30].

EM. G. Capodaglio зазначає, що фізична активність $є$ важливим терапевтичним інструментом для пацієнтів із ХОЗЛ $[6,26]$.

У висновках численних клінічних настанов, пацієнтам із ХОЗЛ потрібно підтримувати досягнуті ефекти амбулаторної терапії, шляхом участі в домашніх програмах або збільшення рівня фізичної активності [23]. Недостатній рівень фізичної активності негативно впливає на здоров'я хворого, ризик загострення зростає [30]. Зважаючи на те, що особи з ХОЗЛ менш фізично активні, ніж здорові люди того самого віку $[6,25]$, украй важливим для них $є$ дотримання фізично активного способу життя. Однак рівень фізичної активності осіб із ХОЗЛ часто обмежує не лише фізичний, але й поведінковий компонент (страх, відсутність мотивації, чинники навколишнього середовища тощо) [31].

Тренування на розвиток сили й витривалості є важливими складниками фізичної активності при ХОЗЛ [31]. Тренування 3 метою збільшення витривалості для пацієнтів із ХОЗЛ може бути різним, наприклад звичайна ходьба в парку, заняття в спортивному залі, плавання, біг, їзда на велосипеді, вправи спортивних тренажерах, скандинавська ходьба тощо.

Однією з причин зниження загальної щоденної фізичної активності пацієнтів із ХОЗЛ є зниження сили чотириголового м'яза стегна [17], що в середньому становить $30 \%$, порівняно зі здоровими людьми [26]. Аеробне тренування, розглядається як метод терапії для полегшення цих симптомів. Tarigan A. P., et al. довели, що тренування тривалістю один місяць збільшують силу м'язів нижніх кінцівок, а також позитивно впливають на функцію зовнішнього дихання, зменшують задишку та інші симптоми, пов'язані із захворюванням [29]. Значно ефективнішими, порівняно з аеробними тренуваннями на суші, були тренування у воді $[12,22]$, які сприяли збільшенню величини пікових навантажень, витривалості, поліпшували якість життя людей із ХОЗЛ [22].

Для розвитку сили рекомендовано виконувати вправи 3 використанням тренажерів або 3 вагою власного тіла чи із зовнішніми обтяженнями (гантелі, еластичні стрічка, експандери); заняття вдома доступні для осіб із ХОЗЛ, а ефект від таких тренувань подібний, як і під час занять на силових тренажеpax, або навіть перевищує його [15]. Greulich T. et al. досягли позитивних результатів за допомогою індивідуально спрямованих програм, які проводили в амбулаторних умовах із використанням засобів гімнастики [16]. Важливим аспектом фізичної активності пацієнтів із ХОЗЛ у домашніх умовах $€$ вміння здійснювати контроль свого стану не лише під час занять, але й після їх завершення. Однією зі стратегій, яка дає змогу попередити наслідки фізичного перенавантаження, є вдосконалення навичок самоконтролю [32].

Висновки. Запропоновано алгоритм вибору фізичної терапії для пацієнтів із ХОЗЛ та схарактеризовано ії особливості з урахуванням перебігу захворювання.

Критеріями під час вибору фізичної терапії визначено стан хворого, рівень задишки, показник $\mathrm{OФB}_{1}$, рівень фізичної активності. Критеріями включення хворого в легеневу реабілітацію є вперше встановлене захворювання, стан після загострення, стан функції зовнішнього дихання. Критеріями повторної участі в програмі ЛР є термін більше року після завершення попередньої програми ЛР, висока мотивація пацієнта з низьким рівнем «залишкових» знань.

Фізична терапія $є$ необхідним компонентом реабілітації в період загострення хронічного обструктивного захворювання легень й обов'язкова частина програм легеневої реабілітації.

Зміст фізичної терапії залежить від перебігу та ступеня захворювання. У період загострення фізична терапія $\epsilon$ самостійною складовою частиною лікування, основна мета якої - сприяти очищенню дихальних шляхів, оптимізувати механізм відкашлювання та поліпшити легеневу вентиляцію легень.

У період стабільного перебігу захворювання фізична терапія стає компонентом програм легеневої реабілітації й реалізується пацієнтом у рамках сеансів із фізичним терапевтом, занять спланованою фізичною активністю, занять силовими вправами.

\section{Джерела та література}

1. Тимрук-Скоропад, К. А. Методи дослідження ефективності фізичної терапії та легеневої реабілітації осіб 3 хронічним обструктивним захворюванням легень (аналіз систематичних оглядів). Здоров'я, спорт, реабілітащія. 2018. Вип. 4, № 4. С. 148-157. doi.org/10.5281/zenodo. 1468312 
2. Тимрук-Скоропад, К. Дисфункція скелетних м'язів при хронічному обструктивному захворюванні легень. Молода спортивна наука України. 2017. Вип. 3. С. 100-101.

3. Тимрук-Скоропад, К., Ступницька, С., Павлова, Ю. Місце фізичної терапії в системі легеневої реабілітації при хронічному обструктивному захворюванні легень (аналіз клінічних настанов). Фізичне виховання, спорт і культура здоров'я у сучасному суспільстві. 2018. Вип. 2, № 42. С. 126-134. doi.org/10.29038/2220-7481-2018-02-126-134

4. Bolton, C. E., Bevan-Smith, E. F., Blakey, J. D., та ін. BTS Guideline on Pulmonary Rehabilitation in Adults British. Thorax. 2013. Vol. 68. P. 111-130. doi.org/10.1136/thoraxjnl-2013-203808

5. Cambach, W., Wagenaar, R. C., Koelman, T. W., et. al. The long-term effects of pulmonary rehabilitation in patients with asthma and chronic obstructive pulmonary disease: a research synthesis. Database of Abstracts of Reviews of Effects (DARE) [Internet]. 1999.

6. Capodaglio, E. M. Physical activity, tool for the prevention and management of chronic diseases. Giornale italiano di medicina del lavoro ed ergonomia. 2018. Vol. 40, No. 2. P. 106-119. doi.org/10.3389/ fphys.2019.00286

7. Charikiopoulou, M., Nikolaidis, P. T., Knechtle, B., et. al. Subjective and Objective Outcomes in Patients With COPD After Pulmonary Rehabilitation - The Impact of Comorbidities. Frontiers in physiology. 2019. Vol. 10. P. 286. doi.org/10.3389/fphys.2019.00286

8. Chick, D. A., Grant, P. J., Harrison, R. V., et. al. Chronic obstructive pulmonary disease patient: guidelines for clinical care ambulatory. 2017. 28 p.

9. Egan, C., Deering, B. M., Blake, C., et. al. Short term and long term effects of pulmonary rehabilitation on physical activity in COPD. Respiratory Medicine. 2012. Vol. 106, No. 12. P. 1671-1679. doi.org/10.1016/j.rmed.2012.08.016

10. Finnerty, J. P., Keeping, I., Bullough, I., et. al. The effectiveness of outpatient pulmonary rehabilitation in chronic lung disease: a randomized controlled trial. Chest. 2001. Vol. 119, No. 6. P. 1705-1710. doi.org/10.1378/CHEST.119.6.1705

11. Furlanetto, K. C., Donária, L., Schneider, L. P., et. al. Sedentary behavior is an independent predictor of mortality in subjects with COPD. Respiratory Care. 2017. Vol. 62, No. 5. P. 579-587. doi.org/10.4187/respcare.05306

12. Gallo-Silva, B. ., Cerezer-Silva, V. ., Ferreira, D., et. al. Effects of water-based aerobic interval training in patients with copd: a randomized controlled trial. Journal of Cardiopulmonary Rehabilitation and Prevention. 2019. Vol. 39, No. 2. P. 105-111. doi.org/10.1097/hcr.0000000000000352

13. Gentry, S., Gentry, B. Chronic obstructive pulmonary disease: diagnosis and management. American family physician. 2017. Vol. 95, No. 7. P. 433-441.

14. Global Initiative for Chronic Obstructive Lung Disease: Pocket guide to COPD diagnosis, management, and prevention. A Guide for Health Care Professionals. 2019.

15. Gosselink, R., Langer, D., Burtin, C., et. al. KNGF - Guideline Chronic obstructive pulmonary disease: Practice guidelines. Dutch Journal of Physical Therapy. 2008. Vol. 118, No. 4. P. 1-64.

16. Greulich, T., Kehr, K., Nell, C., et. al. A randomized clinical trial to assess the influence of a three months training program (gym-based individualized vs. calisthenics-based non-invidualized) in COPD-patients. Respiratory research. 2014. Vol. 15, No. 1. P. 36. doi.org/10.1186/1465-9921-15-36

17. Güell, R., Casan, P., Belda, J., et. al. Long-term effects of outpatient rehabilitation of COPD: a randomized trial. Chest. 2000. Vol. 117, No. 4. P. 976-983. doi.org/10.1378/CHEST.117.4.976

18. Ko, F. W., Chan, K. P., Hui, D. S., et. al. Acute exacerbation of COPD. Respirology. 2016. Vol. 21 , No. 7. P. 1152-1165. doi.org/10.1111/resp.12780

19. Koskela, J., Kilpeläinen, M., Kupiainen, H., et. al. Co-morbidities are the key nominators of the health related quality of life in mild and moderate COPD. BMC Pulmonary Medicine. 2014. Vol. 14, No. 1. P. 1-11. doi.org/10.1186/1471-2466-14-102

20. Kruis, A. L., Boland, M. R. S., Assendelft, W. J. J., et. al. Effectiveness of integrated disease management for primary care chronic obstructive pulmonary disease patients: results of cluster randomised trial. BMJ (Clinical research ed.). 2014. Vol. 349. P. g5392. doi.org/10.1136/bmj.g5392

21. Lorenz, J., Bals, R., Dreher, M., et. al. Expertentreffen COPD: Exazerbation der COPD. Pneumologie. 2017. Vol. 71, No. 05. P. 269-289. doi.org/10.1055/s-0043-106559

22. McNamara, R. J., McKeough, Z. J., McKenzie, D. K., et. al. Water-based exercise in COPD with physical comorbidities: a randomised controlled trial. The European respiratory journal. 2013. Vol. 41, No. 6. P. 128491. doi.org/10.1183/09031936.00034312

23. Meshe, O. F., Claydon, L. S., Bungay, H., et. al. The relationship between physical activity and health status in patients with chronic obstructive pulmonary disease following pulmonary rehabilitation. Disability and Rehabilitation. 2017. Vol. 39, No. 8. P. 746-756. doi.org/10.3109/09638288.2016.1161842

24. Puente-Maestu, L., Luisa Sánz, M., Sánz, P., et. al. Long-term effects of a maintenance program after supervised or self-monitored training programs in patients with COPD. Lung. 2003. Vol. 181, No. 2. P. 67-78. doi.org/10.1007/s00408-003-1007-0 
25. Ries, A. L., Kaplan, R. M., Myers, R., et. al. Maintenance after pulmonary rehabilitation in chronic lung disease. American Journal of Respiratory and Critical Care Medicine. 2003. Vol. 167, No. 6. P. 880-888. doi.org/10.1164/rccm.200204-3180C

26. Schneider, L. P., Furlanetto, K. C., Rodrigues, A., et. al. Sedentary Behaviour and Physical Inactivity in Patients with Chronic Obstructive Pulmonary Disease: Two Sides of the Same Coin? COPD: Journal of Chronic Obstructive Pulmonary Disease. 2018. Vol. 15, No. 5. P. 432-438. doi.org/10.1080/15412 555.2018 .1548587

27. Simonÿ, C., Andersen, I. C., Bodtger, U., et. al. Breathing through a troubled life - a phenomenologicalhermeneutic study of chronic obstructive pulmonary disease patients' lived experiences during the course of pulmonary rehabilitation. International Journal of Qualitative Studies on Health and Well-being. 2019. Vol. 14, No. 1. P. 164-74. doi.org/10.1080/17482631.2019.1647401

28. Singh, S. J., Steiner, M. C. Pulmonary rehabilitation; what's in a name? Thorax. 2013. Vol. 68, No. 10. P. 899901. doi.org/10.1136/thoraxjnl-2013-203716

29. Tarigan, A. P., Pandia, P., Mutiara, E., et. al. Impact of lower-limb endurance training on dyspnea and lung functions in patients with COPD. Macedonian journal of medical sciences. 2018. Vol. 6, No. 12. P. 23542358. doi.org/10.3889/oamjms.2018.381

30. Troosters, T., Blondeel, A., Janssens, W., et. al. The past, present and future of pulmonary rehabilitation. Respirology. 2019. doi.org/10.1111/resp.13517

31. Yang, I. A., Brown, J. L., George, J., et. al. COPD-X Australian and New Zealand guidelines for the diagnosis and management of chronic obstructive pulmonary disease: 2017 update. The Medical journal of Australia. 2017. Vol. 207, No. 10. P. 436-442.

32.Zwerink, T., Brusse-Keizer, M., Van der Valk, P. P., et. al. Self management for patients with chronic obstructive pulmonary disease (Cochrane review) [with consumer summary]. Cochrane Database of Systematic Reviews. 2014;Issue 3. doi.org/10.1002/14651858.CD002990.pub3

\section{References}

1. Tymruk-Skoropad, K. (2018). Methods of studying the effectiveness of physical therapy and pulmonary rehabilitation of COPD patients (systematic review). Health, sport, rehabilitation, 4(4), 148-157. doi.org/10.5281/zenodo.1468312 (in Ukrainian).

2. Tymruk-Skoropad K. (2017). Dysfunction of peripheral muscle through the chronic obstructive pulmonary disease. Young sport science of Ukraine, T. 3, c. 100- 101. (in Ukrainian).

3. Tymruk-Skoropad, K., Stupnycka, S., \& Pavlova, I. (2018). The role of physical therapy in the system of pulmonary rehabilitation in the case of chronic obstructive pulmonary disease (the analysis of clinical guidelines). Physical education, sports and health culture in today's society, 2(42), 126-134. doi.org/10.29038/2220-7481-2018-02-126-134 (in Ukrainian).

4. Bolton, C. E., Bevan-Smith, E. F., Blakey, J. D., Crowe, P., Elkin, S. L., Garrod, R., Walmsley, S. (2013). BTS Guideline on Pulmonary Rehabilitation in Adults British. Thorax, 68, ii1-ii30. doi.org/10.1136/thoraxjnl-2013203808

5. Cambach, W., Wagenaar, R. C., Koelman, T. W., Ton Van Keimpema, A. R. J., \& Kemp\& Phb, H. C. G. (1999). The Long-Term Effects of Pulmonary Rehabilitation in Patients With Asthma and Chronic Obstructive Pulmonary Disease: A Research Synthesis. In Arch Phys Med Rehabil, 80, 103-111.

6. Capodaglio, E. M. (2018). [Physical activity, tool for the prevention and management of chronic diseases]. Giornale Italiano Di Medicina Del Lavoro Ed Ergonomia, 40(2), 106-119. doi.org/10.3389/fphys.2019.00286

7. Charikiopoulou, M., Nikolaidis, P. T., Knechtle, B., Rosemann, T., Rapti, A., \& Trakada, G. (2019). Subjective and Objective Outcomes in Patients With COPD After Pulmonary Rehabilitation - The Impact of Comorbidities. Frontiers in Physiology, 10, 286. doi.org/10.3389/fphys.2019.00286

8. Chick, D. A., Grant, P. J., Harrison, R. V., Othman, A., Roark, S. E., \& Han, M. K. (2017). Chronic Obstructive Pulmonary Disease Patient: Guidelines for Clinical Care Ambulatory, 28.

9. Egan, C., Deering, B. M., Blake, C., Fullen, B. M., McCormack, N. M., Spruit, M. A., \& Costello, R. W. (2012). Short term and long term effects of pulmonary rehabilitation on physical activity in COPD. Respiratory Medicine, 106(12), 1671-1679. doi.org/10.1016/j.rmed.2012.08.016

10. Finnerty, J. P., Keeping, I., Bullough, I., \& Jones, J. (2001). The Effectiveness of Outpatient Pulmonary Rehabilitation in Chronic Lung Disease: A Randomized Controlled Trial. Chest, 119(6), 1705-1710. doi.org/10.1378/CHEST.119.6.1705

11. Furlanetto, K. C., Donária, L., Schneider, L. P., Lopes, J. R., Ribeiro, M., Fernandes, K. B., Pitta, F. (2017). Sedentary Behavior Is an Independent Predictor of Mortality in Subjects With COPD. Respiratory Care, 62(5), 579-587. doi.org/10.4187/respcare.05306

12. Gallo-Silva, B. ., Cerezer-Silva, V. ., Ferreira, D., et. al. (2019). Effects of water-based aerobic interval training in patients with copd: a randomized controlled trial. Journal of Cardiopulmonary Rehabilitation and Prevention, 39(2), 105-111. doi.org/10.1097/hcr.0000000000000352 
13. Gentry, S., \& Gentry, B. (2017). Chronic Obstructive Pulmonary Disease: Diagnosis and Management. American Family Physician, 95(7), 433-441.

14. GOLD. (2019). Global Initiative for Obstructive Lung Disease, guidelines, 2019.

15. Gosselink, R., Langer, D., Burtin, C., Probst, V., Hendriks, H. J. M., van der Schans, C. P., Muris, J. (2008). KNGF - Guideline Chronic obstructive pulmonary disease Practice guidelines. Supplement to the Dutch Journal of Physical Therapy, 118(4), 1-64.

16. Greulich, T., Kehr, K., Nell, C., Koepke, J., Haid, D., Koehler, U., ... Koczulla, A.-R. (2014). A randomized clinical trial to assess the influence of a three months training program (gym-based individualized vs. calisthenics-based non-invidualized) in COPD-patients. Respiratory Research, 15(1), 36. hdoi.org/10.1186/ 1465-9921-15-36

17. Güell, R., Casan, P., Belda, J., Sangenis, M., Morante, F., Guyatt, G. H., \& Sanchis, J. (2000). Long-term Effects of Outpatient Rehabilitation of COPD: A Randomized Trial. Chest, 117(4), 976-983. doi.org/10.1378/ CHEST.117.4.976

18. Ko, F. W., Chan, K. P., Hui, D. S., Goddard, J. R., Shaw, J. G., Reid, D. W., \& Yang, I. A. (2016). Acute exacerbation of COPD. Respirology, 21(7), 1152-1165. doi.org/10.1111/resp.12780

19. Koskela, J., Kilpeläinen, M., Kupiainen, H., Mazur, W., Sintonen, H., Boezen, M., Laitinen, T. (2014). Comorbidities are the key nominators of the health related quality of life in mild and moderate COPD. BMC Pulmonary Medicine, 14(1), 1-11. doi.org/10.1186/1471-2466-14-102

20. Kruis, A. L., Boland, M. R. S., Assendelft, W. J. J., Gussekloo, J., Tsiachristas, A., Stijnen, T., Chavannes, N. H. (2014). Effectiveness of integrated disease management for primary care chronic obstructive pulmonary disease patients: results of cluster randomised trial. BMJ (Clinical Research Ed.), 349, g5392. doi.org/ $10.1136 /$ bmj.g5392

21.Lorenz, J., Bals, R., Dreher, M., Jany, B., Koczulla, R., Pfeifer, M., Windisch, W. (2017). Expertentreffen COPD: Exazerbation der COPD. Pneumologie, 71(05), 269-289. doi.org/10.1055/s-0043-106559

22. McNamara, R. J., McKeough, Z. J., McKenzie, D. K., \& Alison, J. A. (2013). Water-based exercise in COPD with physical comorbidities: a randomised controlled trial. The European Respiratory Journal, 41(6), 12841291. doi.org/10.1183/09031936.00034312

23. Meshe, O. F., Claydon, L. S., Bungay, H., \& Andrew, S. (2017). The relationship between physical activity and health status in patients with chronic obstructive pulmonary disease following pulmonary rehabilitation. Disability and Rehabilitation, 39(8), 746-756. doi.org/10.3109/09638288.2016.1161842

24. Puente-Maestu, L., Luisa Sánz, M., Sánz, P., de Oña, R. J. M., Arnedillo, A., \& Casaburi, R. (2003). LongTerm Effects of a Maintenance Program After Supervised or Self-Monitored Training Programs in Patients with COPD. Lung, 181(2), 67-78. doi.org/10.1007/s00408-003-1007-0

25. Ries, A. L., Kaplan, R. M., Myers, R., \& Prewitt, L. M. (2003). Maintenance after Pulmonary Rehabilitation in Chronic Lung Disease. American Journal of Respiratory and Critical Care Medicine, 167(6), 880-888. doi.org/10.1164/rccm.200204-3180C

26. Schneider, L. P., Furlanetto, K. C., Rodrigues, A., Lopes, J. R., Hernandes, N. A., \& Pitta, F. (2018). Sedentary Behaviour and Physical Inactivity in Patients with Chronic Obstructive Pulmonary Disease: Two Sides of the Same Coin? COPD: Journal of Chronic Obstructive Pulmonary Disease, 15(5), 432-438. doi.org/10.1080/ 15412555.2018.1548587

27. Simonÿ, C., Andersen, I. C., Bodtger, U., \& Birkelund, R. (2019). Breathing through a troubled life - a phenomenological-hermeneutic study of chronic obstructive pulmonary disease patients' lived experiences during the course of pulmonary rehabilitation. International Journal of Qualitative Studies on Health and WellBeing, 14(1), 1647401. doi.org/10.1080/17482631.2019.1647401

28. Singh, S. J., \& Steiner, M. C. (2013). Pulmonary rehabilitation; what's in a name? Thorax, 68(10), 899-901. doi.org/10.1136/thoraxjnl-2013-203716

29. Tarigan, A. P., Pandia, P., Mutiara, E., Pradana, A., Rhinsilva, E., \& Efriyandi, E. (2018). Impact of LowerLimb Endurance Training on Dyspnea and Lung Functions in Patients with COPD. Open Access Macedonian Journal of Medical Sciences, 6(12), 2354-2358. doi.org/10.3889/oamjms.2018.381

30. Troosters, T., Blondeel, A., Janssens, W., \& Demeyer, H. (2019). The past, present and future of pulmonary rehabilitation. Respirology. doi.org/10.1111/resp.13517

31. Yang, I. A., Brown, J. L., George, J., Jenkins, S., McDonald, C. F., McDonald, V. M., Dabscheck, E. (2017). COPD-X Australian and New Zealand guidelines for the diagnosis and management of chronic obstructive pulmonary disease: 2017 update. The Medical Journal of Australia, 207(10), 436-442.

32.Zwerink, T., Brusse-Keizer, M., van der Valk, P. P., Zielhuis, G., Monninkhof, E., van der Palen, J., \& Frith, P. (n.d.). Self management for patients with chronic obstructive pulmonary disease (Cochrane review) [with consumer summary]. Cochrane Database of Systematic Reviews, 2014; Issue 3. doi.org/10.1002/146518 58.CD002990.pub3 